\title{
Antalya Kemer Sarioren Stream, Longshore Transport Model
}

\author{
Alp Kü̧̈ükosmanoğglu ${ }^{a}$ Özen Arlı Küçükosmanoğlu ${ }^{b}$ and Rifat Tur ${ }^{c^{*}}$ \\ ${ }^{a, b}$ Mehmet Akif Ersoy University, Civil Engineering Department \\ $c^{*}$ Akdeniz University, Civil Engineering Department \\ ${ }^{*}$ E-mail address: rifattur@akdeniz.edu.tr \\ Received date: October 2016 \\ Accepted date: November 2016
}

\begin{abstract}
Whether natural occurrence of a beach takes thousands of years, it takes a few years to totally erode it by mismanaged use of humanbeing. Beaches are important for tourism and human settlements. In this study, a part of Çamyuva Beach located on the south of Kemer district of Antalya Province has been modelled to forecast of coastal line change after construction of a groin structure for prevention of closure of stream mouth. Çamyuva beach is $5 \mathrm{~km}$ in length. The model results show that, the closure can be prevented by construction of a $30 \mathrm{~m}$ groin.
\end{abstract}

Keywords: Modelling, Longshore Sediment Transport, Erosion

\section{Introduction}

The coastal zones are dynamic places that host many sectors and uses. Beaches, as a precious part of coastal zones, are critical habitats and highly demanded. Tourism is an important sector for Antalya, and for the study area, Çamyuva. Antalya is a popular tourist destination. Between years 2012 to 2015, an average of 10 million foreigner per year visited Antalya region, while domestic visitor counts are around 450000 [1]. Almost one quarter of the tourists of Antalya accommodate in Kemer Region [2]. In 1991, Çamyuva takes place on 1/25.000 scale of South West Antalya Tourism Development Plan and reported as one of the "Tourism Development Sites" [3]. According to Onur et al. [4] between years 1975 to 2006, population of Kemer was increased from 6000 to 83000 . In the same study, the change of urban settlements increased from 1 ha in 1975 to 462 ha in 1987. The highway opened in 1980s increased the urban growth and tourism settlements in Kemer. The urban settlement increased between 1987 to 1995 and 1995 to 2003 is given as $159 \%$ and 44\% respectively [4]. All these changes show that, the stresses on beaches, where all these settlements are somehow related with tourism and coast, are increased every year by many times.

The protection of hinterland of coasts is highly dependent on beaches and their sustainable uses. There are many example of coastal destruction and erosion related to traditional management efforts not integrated with science and knowledge.

Çamyuva is a sandy beach given in Figure 1. The sediment particle size of the study area is gravel $(\sim 30 \%)$ and sand $(70 \%)$. The $\mathrm{D}_{60}$ and $\mathrm{D}_{10}$ particle size is 1.8 and $0.6 \mathrm{~mm}$ respectively. The width of the beach is between $45-70 \mathrm{~m}$. The width of the southern parts is around $25 \mathrm{~m}$.

Major climate type is Mediterranean climate, having hot, dry summers and cool, wet winters. 


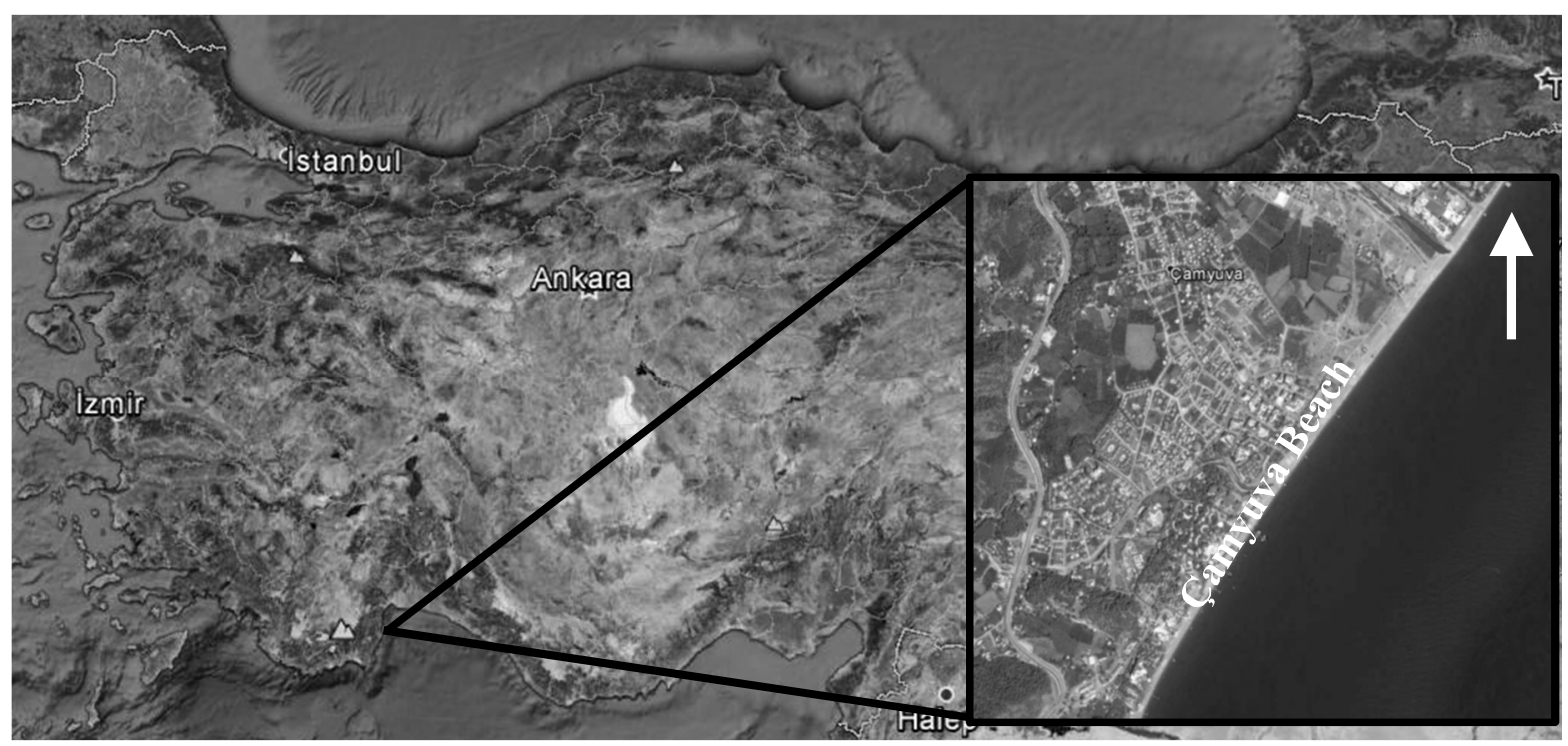

Fig. 1. Study area

\section{Methodology}

In this study, first of all, the regional wave climate was studied and wave parameters were prepared. After climatic parameters, the bathymetry of the region was prepared.

\subsection{Determination of Wave Climate}

The representative station given by "Coast Wind and Deep Water Wave Atlas, 1999" [5] of NATO TU-WAVES Project is $36.50^{\circ} \mathrm{N}, 30.70^{\circ} \mathrm{E}$. The wind rose of the region is given in Figure 2. The dominant wave direction considering coast layout lead to erosion is between south and east. By using wave rose, the wave frequencies are calculated. The frequencies are used in calculation of wave hours. According to the Atlas [5], averages of the monthly maximums are in between $1 \mathrm{~m}$ and $3 \mathrm{~m}$ (Figure 3). The relation between wave heights and wave periods of the region is given in Figure 4.

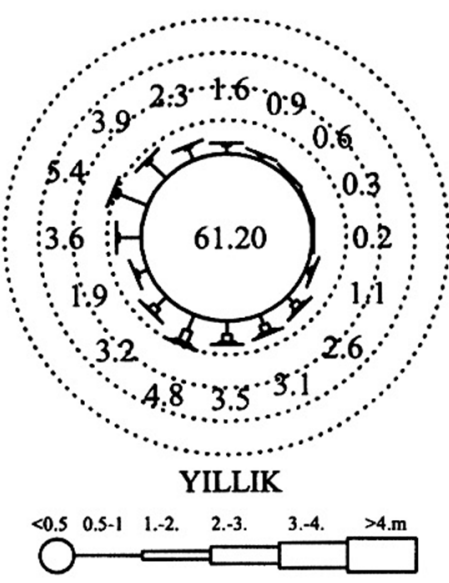

Fig. 2. Yearly wave rose at $36.50^{\circ} \mathrm{N}, 30.70^{\circ} \mathrm{E}$ coordinates of the Atlas (Özhan ve Abdalla, 1999) 


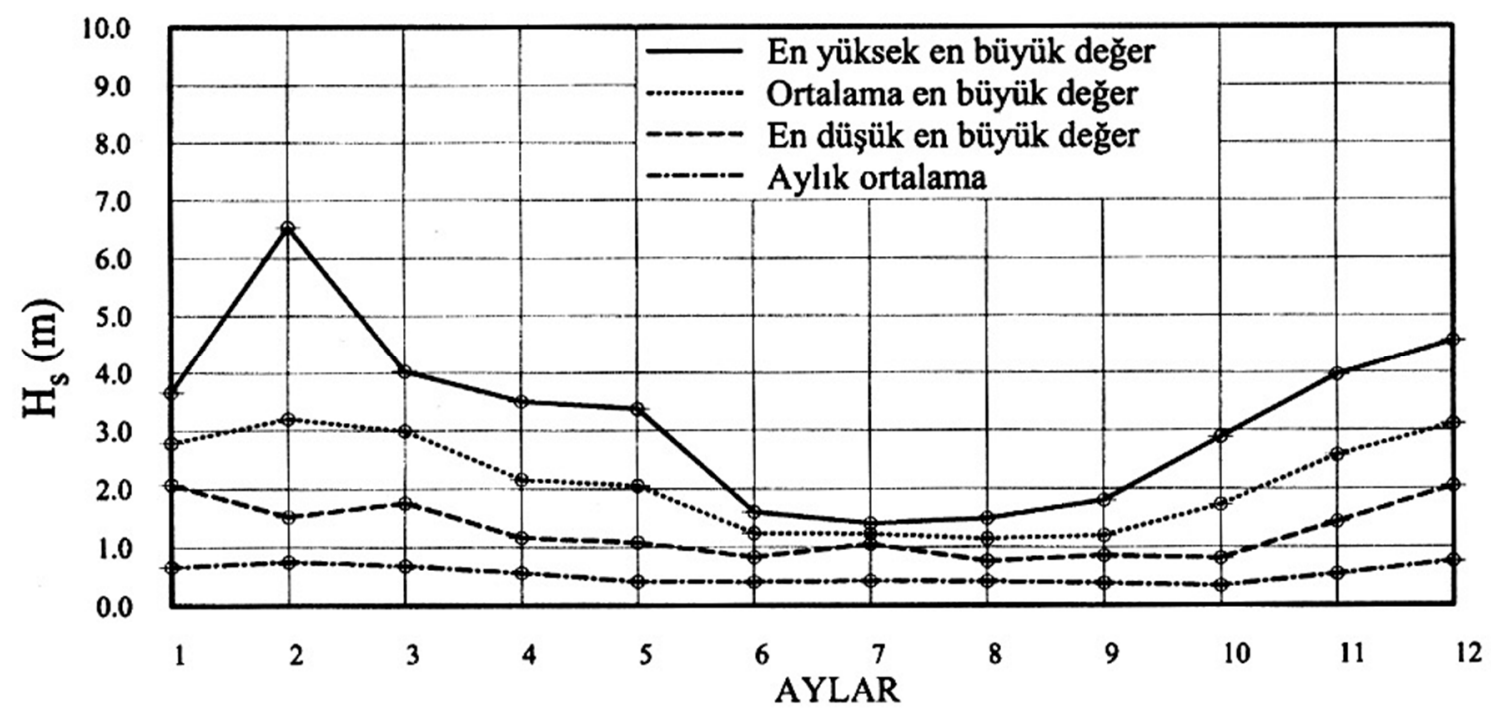

Fig. 3: Monthly average and maximum wave heights of $36.50^{\circ} \mathrm{N}, 30.70^{\circ} \mathrm{E}$ coordinates of the Atlas [5]

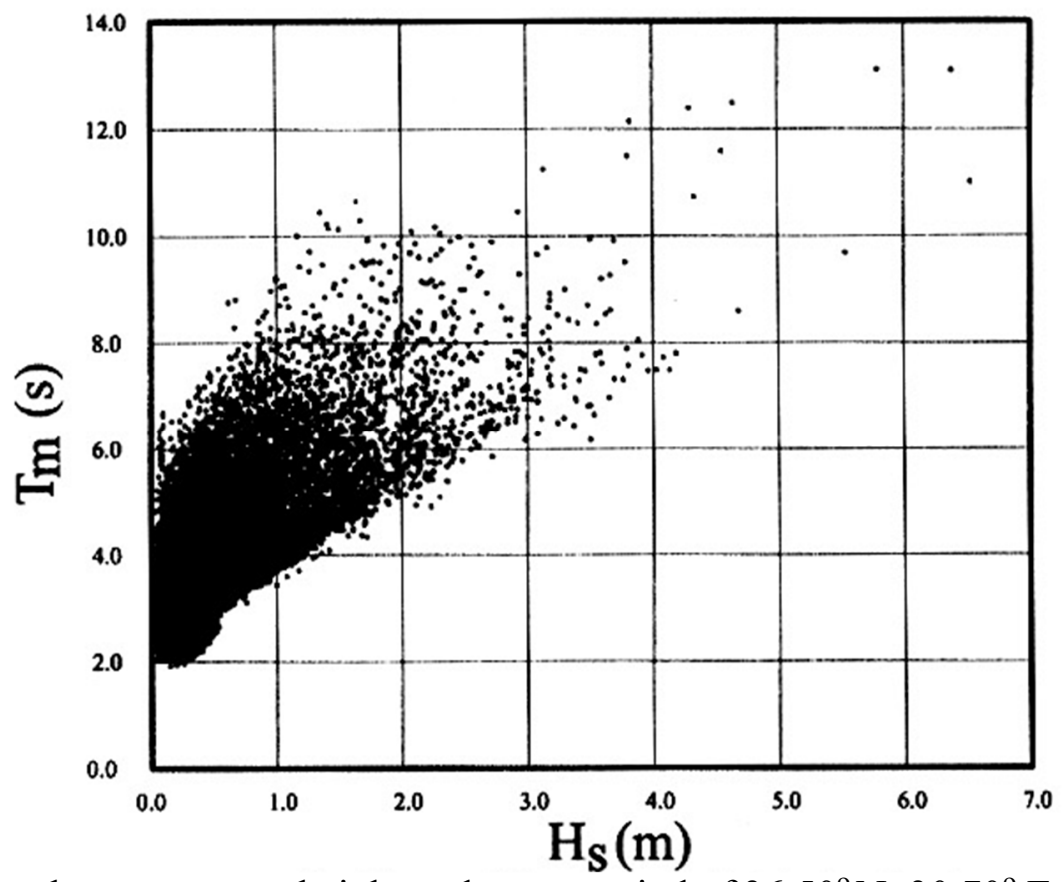

Fig. 4. Relation between wave height and wave period of $36.50^{\circ} \mathrm{N}, 30.70^{\circ} \mathrm{E}$ coordinates of the Atlas [5] 


\subsection{Numerical Modelling}

The coastal change after construction of the groins are examined with the model. In the study, "one dimensional shoreline change model" GENESIS is used $[6,7,8,9,10,11]$.

For every time step $\Delta \mathrm{T}$ and individual grid $\Delta \mathrm{X}$, the longshore currents driven by broken waves are calculated. The current velocity of the next time step is determined by using the boundary conditions and calculated former step current velocities. Simulation is executed for all time steps. After simulation completed, the transported sediment volume can be obtained.

\section{Model application}

In order to model the study area, the bathymetry of the region is digitized by using the maps of Office of Navigation, Hydrography and Oceanography [12]. The bathymetry is given in Figure 5. Bathymetry data is used for obtaining mesh (Figure 6). The bathymetry is also used for wave transformation which carry wave from deeper water to an arbitrary shallower water depth. Wave lead to sediment transport is between south and east. The transformed wave data is given in Figure 7.

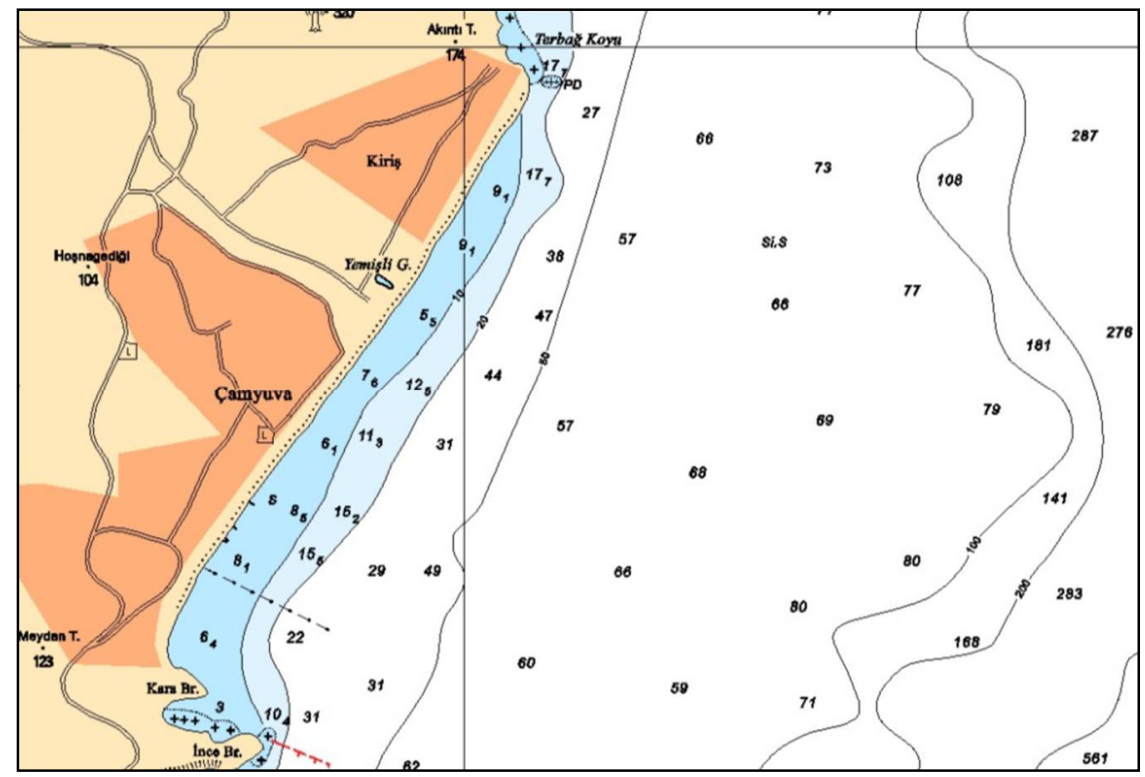

Fig. 5. Bathymetry of the study area [12] 


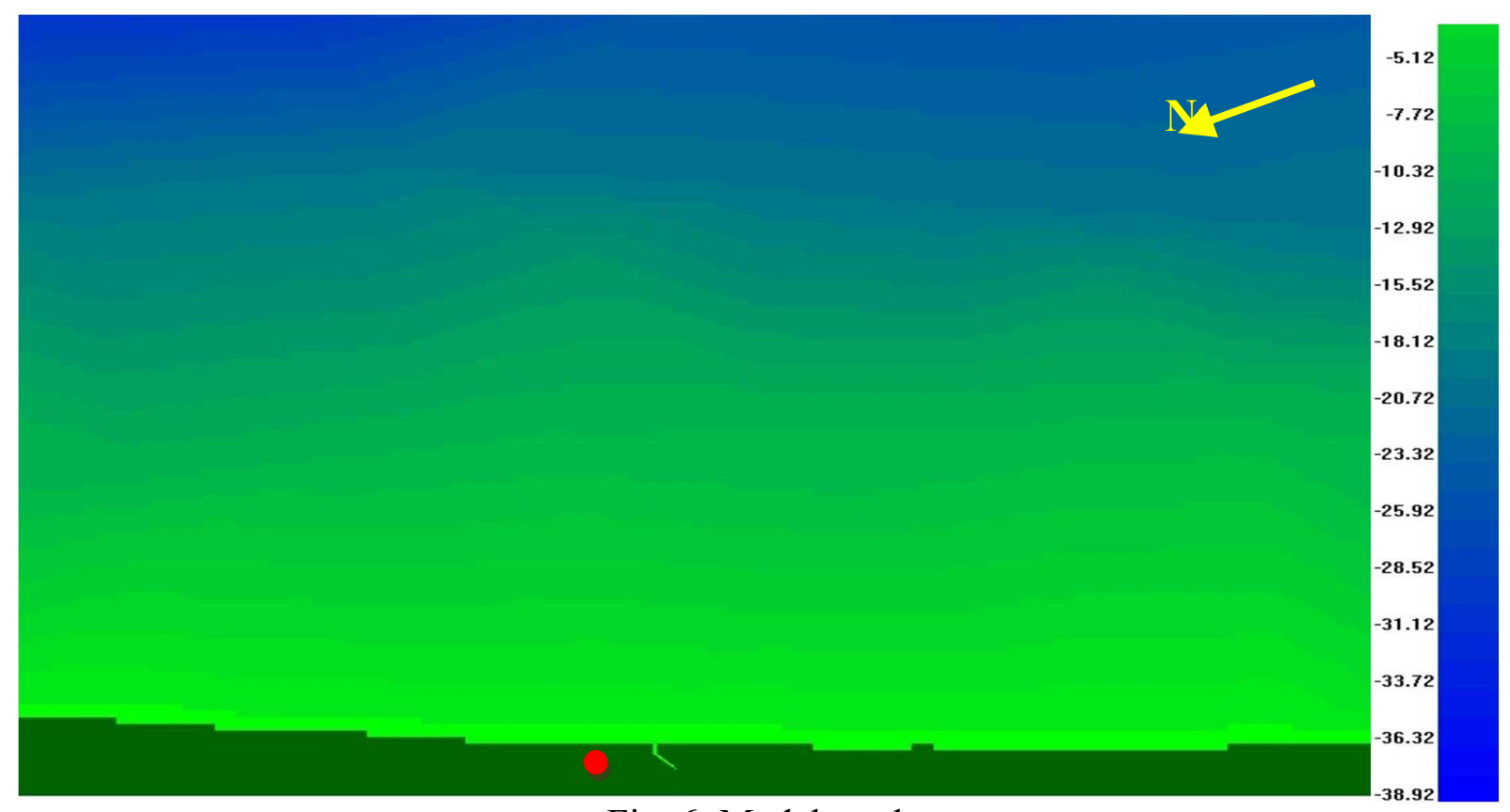

Fig. 6. Model mesh

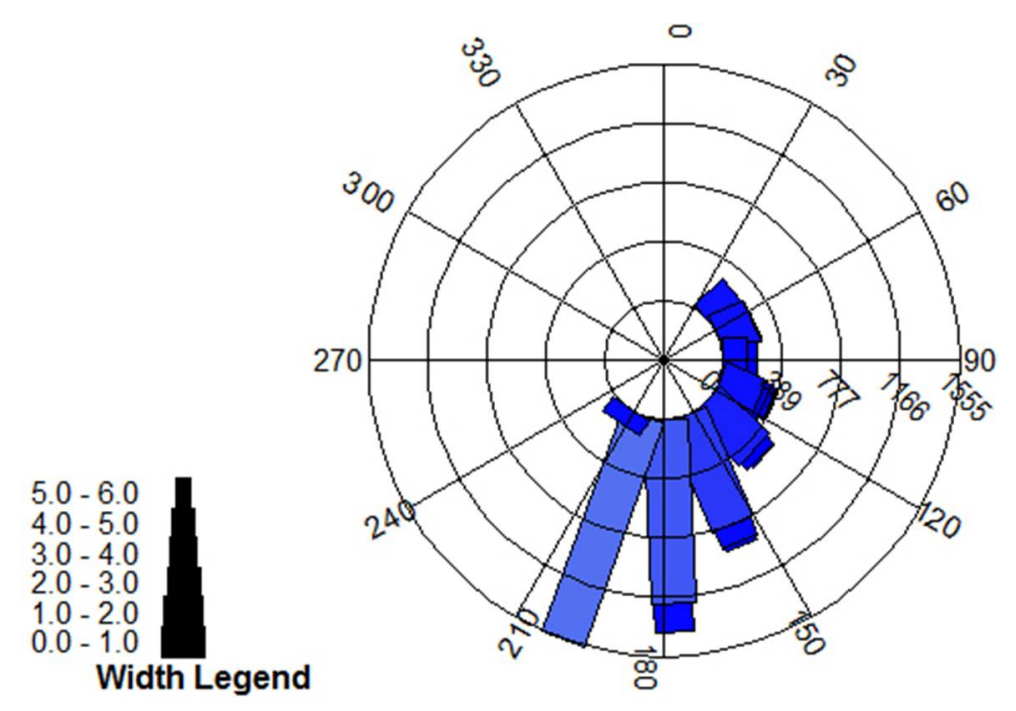

Fig. 7. Wave direction vs wave height, number of occurrences.

\subsection{One Dimensional Sediment Transport Model}

Initial shoreline, bathymetry and wave data is used in one dimensional model (Figure 6).Calculated yearly wave hours are applied to the model. Yearly shoreline changes are obtained by model. Simulation is performed for six years. The effective grain size is taken from sieve analysis of the region, and $\mathrm{D}_{10}$ value is used in the model. The berm height and closure depth is taken as $2 \mathrm{~m}$ and $8 \mathrm{~m}$ respectively. $\mathrm{K}_{1}$ and $\mathrm{K}_{2}$ constants are taken as 0.4 and 0.2 respectively. The groin settlement is given in Figure 8 . The sea depth of groin are $\sim 0.65$ meter. The initial shoreline and groin settlement of model is given in Figure 9. 


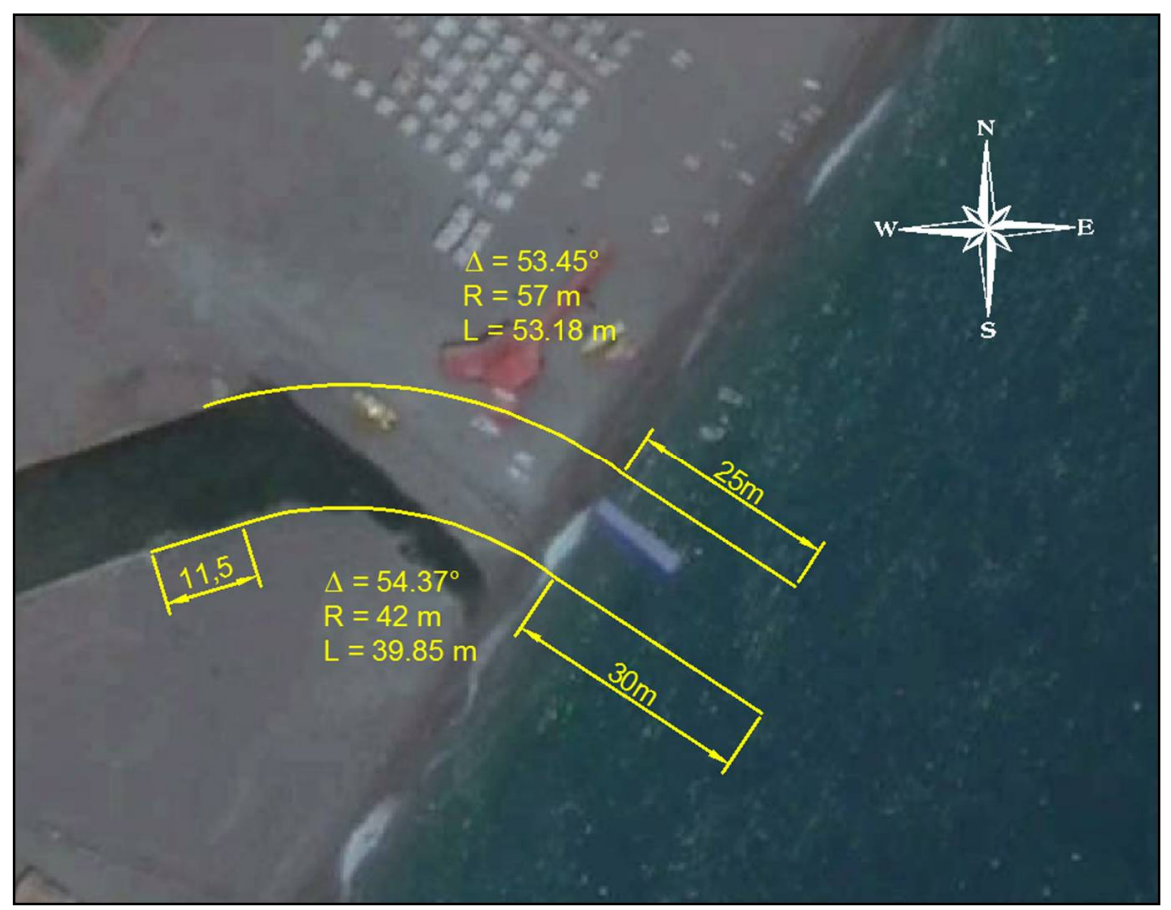

Fig. 8. Groin settlements of the Sarioren Stream mouth [13]

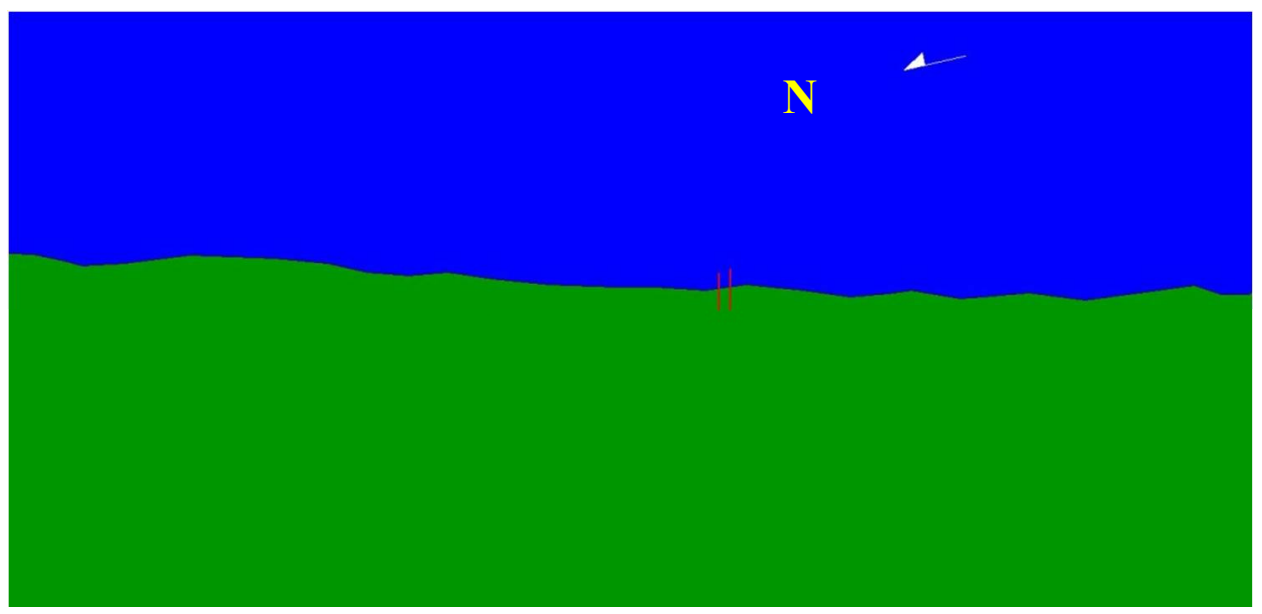

Fig. 9. Groin settlements and initial shoreline of the model

The net sediment transport direction is approximately south to north. The forecasted shoreline after $1^{\text {st }}$ year of construction show that (Figure 10) the northerly waves are resulted in slight sediment deposition $(7-10 \mathrm{~m})$ in the north site of the groin structures. The south side of the structures show 10 to 13 m erosion under the influence of northerly waves. The influence of southerly waves show that (Figure 11) there will be $8 \mathrm{~m}$ and $10 \mathrm{~m}$ deposition and erosion in south and north of groins respectively. At the end of whole year period, there will be no significant shoreline change (Figure 12). After $2^{\text {nd }}$ year simulation, the changes over shoreline are the same as first year (Figure 13 and Figure 14). The 6 year simulation shows that the groin structures are not resulted in deposition of the stream mouth (Figure 15 to Figure 19). 
The sediment transport rates are given in Figure 20. The longshore sediment transport of the region is $186,836 \mathrm{~m}^{3} /$ year from SSW to NNE, and $54,889 \mathrm{~m}^{3} /$ year from NNE to SSW. The net transport direction is from SSW to NNE.

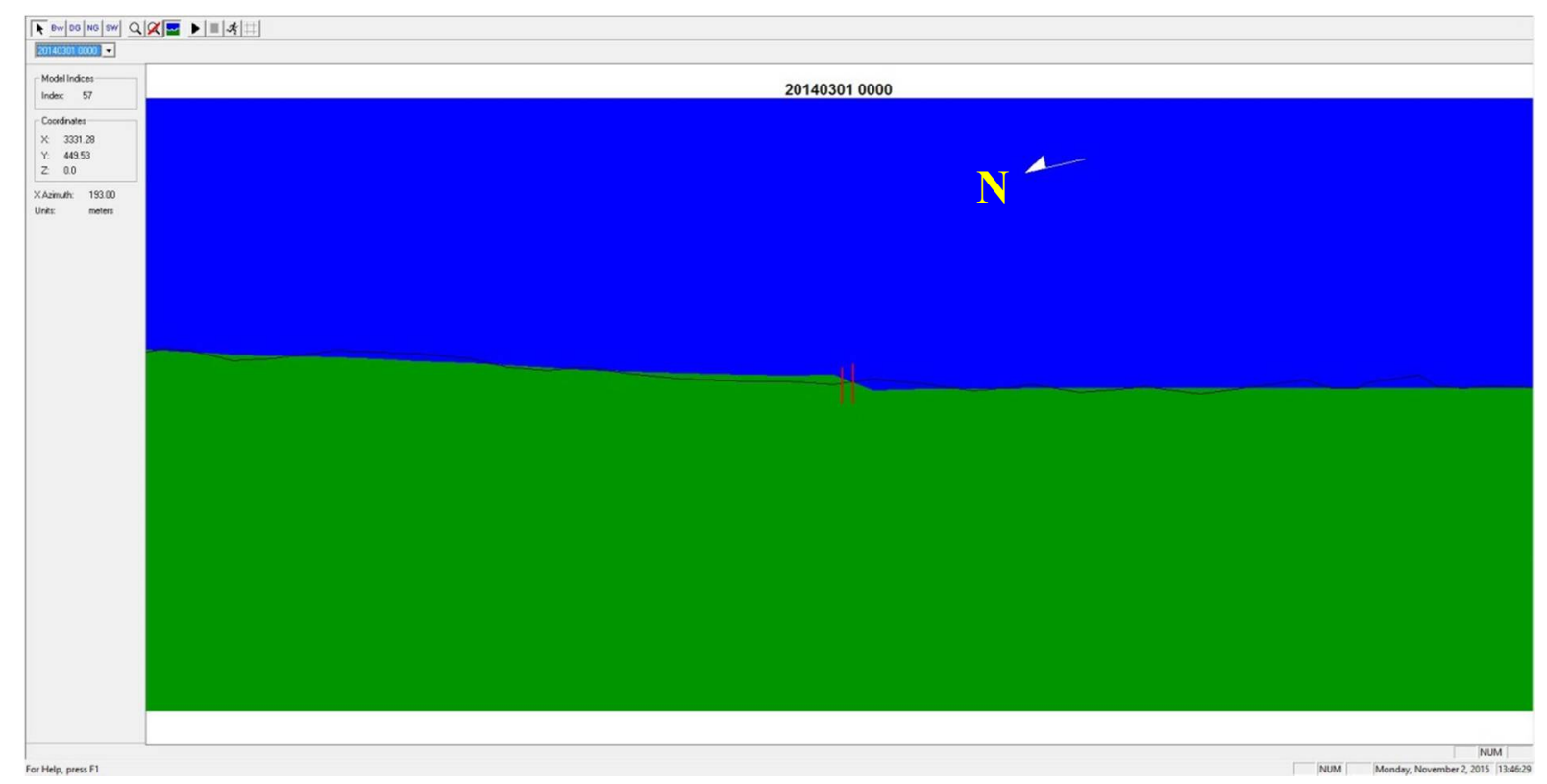

Fig. 10. Forecasted shoreline under the influence of northerly waves ( $1^{\text {st }}$ Year $)$

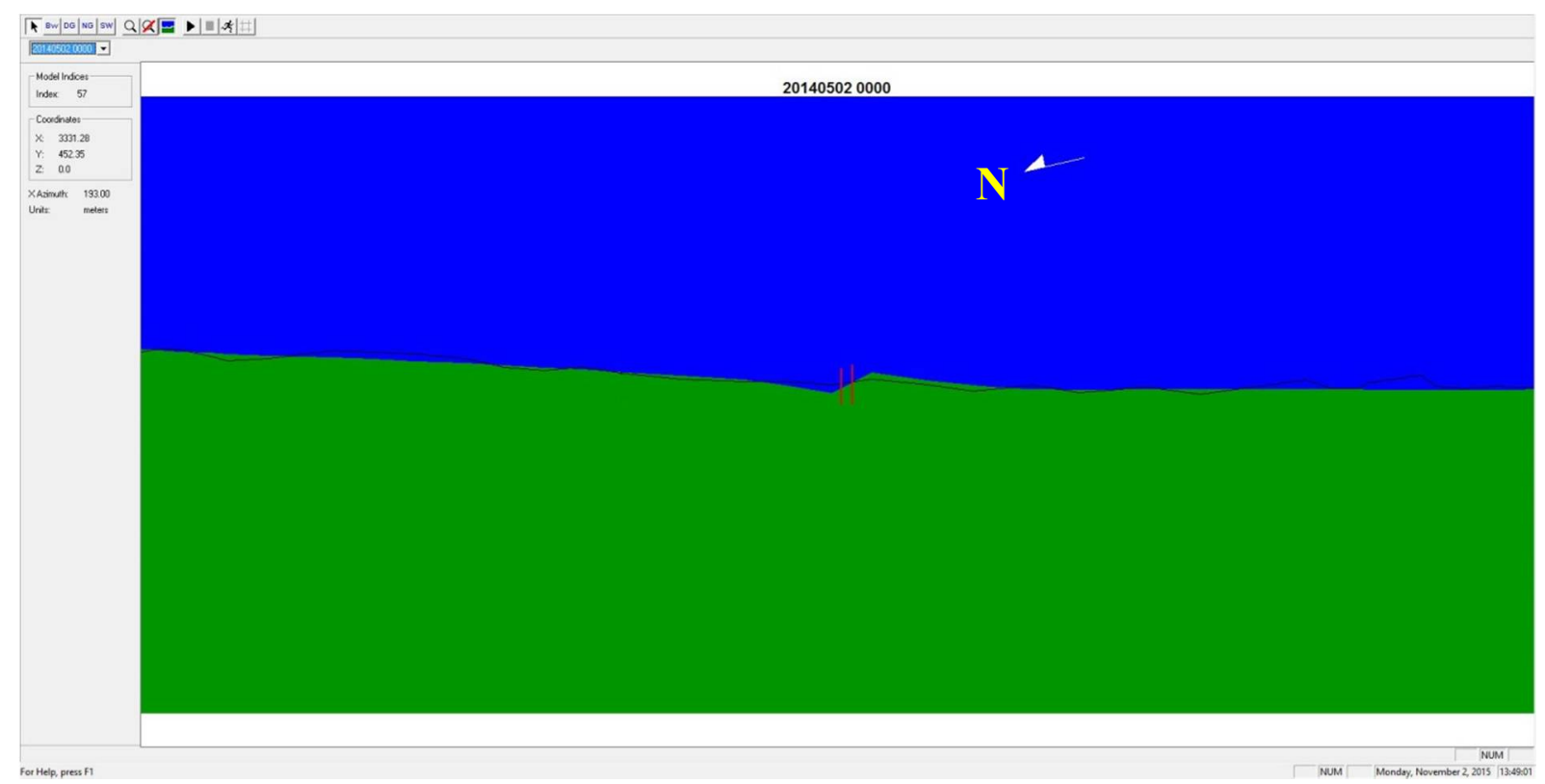

Fig. 11. Forecasted shoreline under the influence of southerly waves $\left(1^{\text {st }}\right.$ Year $)$ 


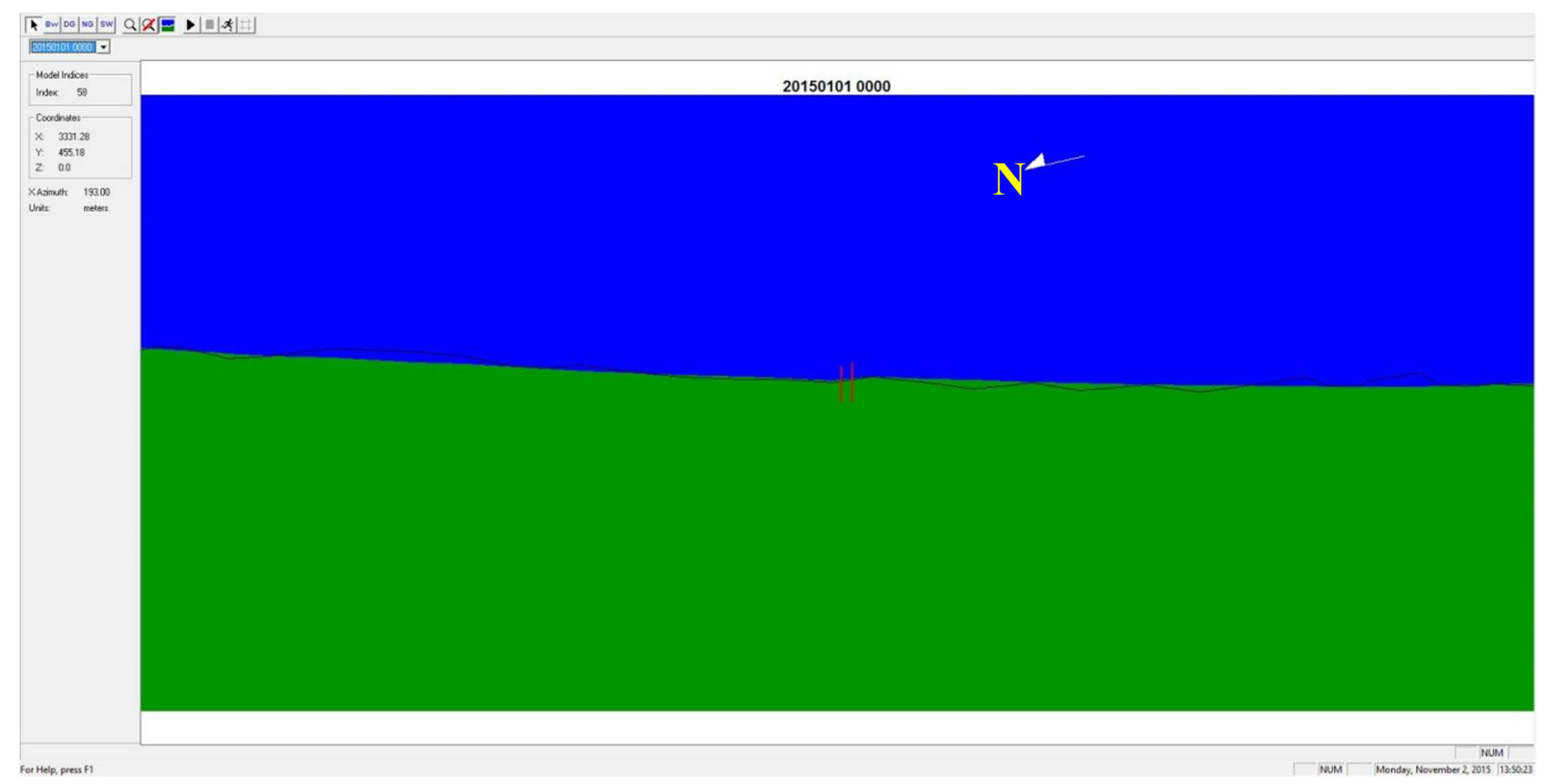

Fig. 12. $1^{\text {st }}$ Year shoreline change forecast

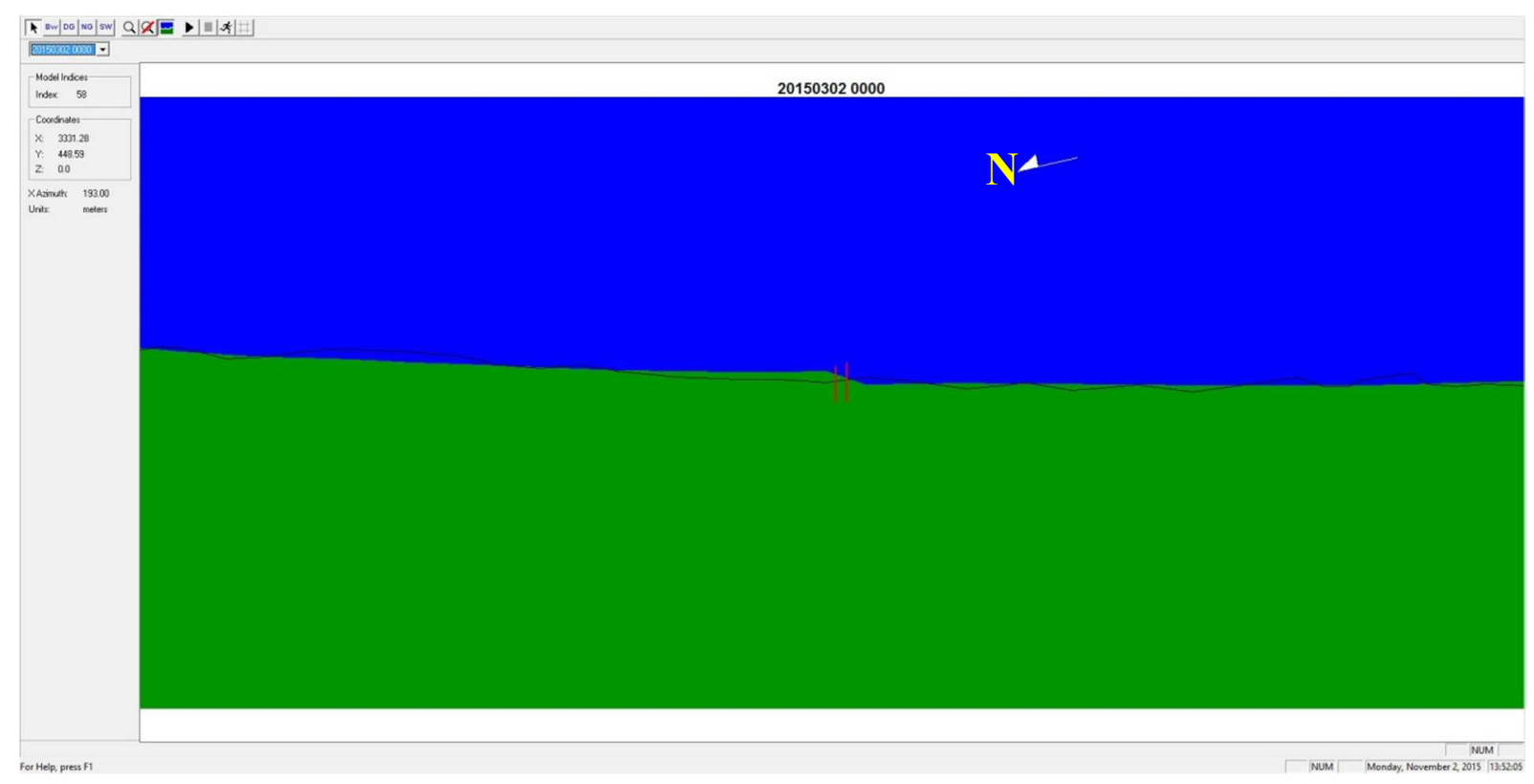

Fig. 13. Forecasted shoreline under the influence of northerly waves ( $2^{\text {nd }}$ Year) 


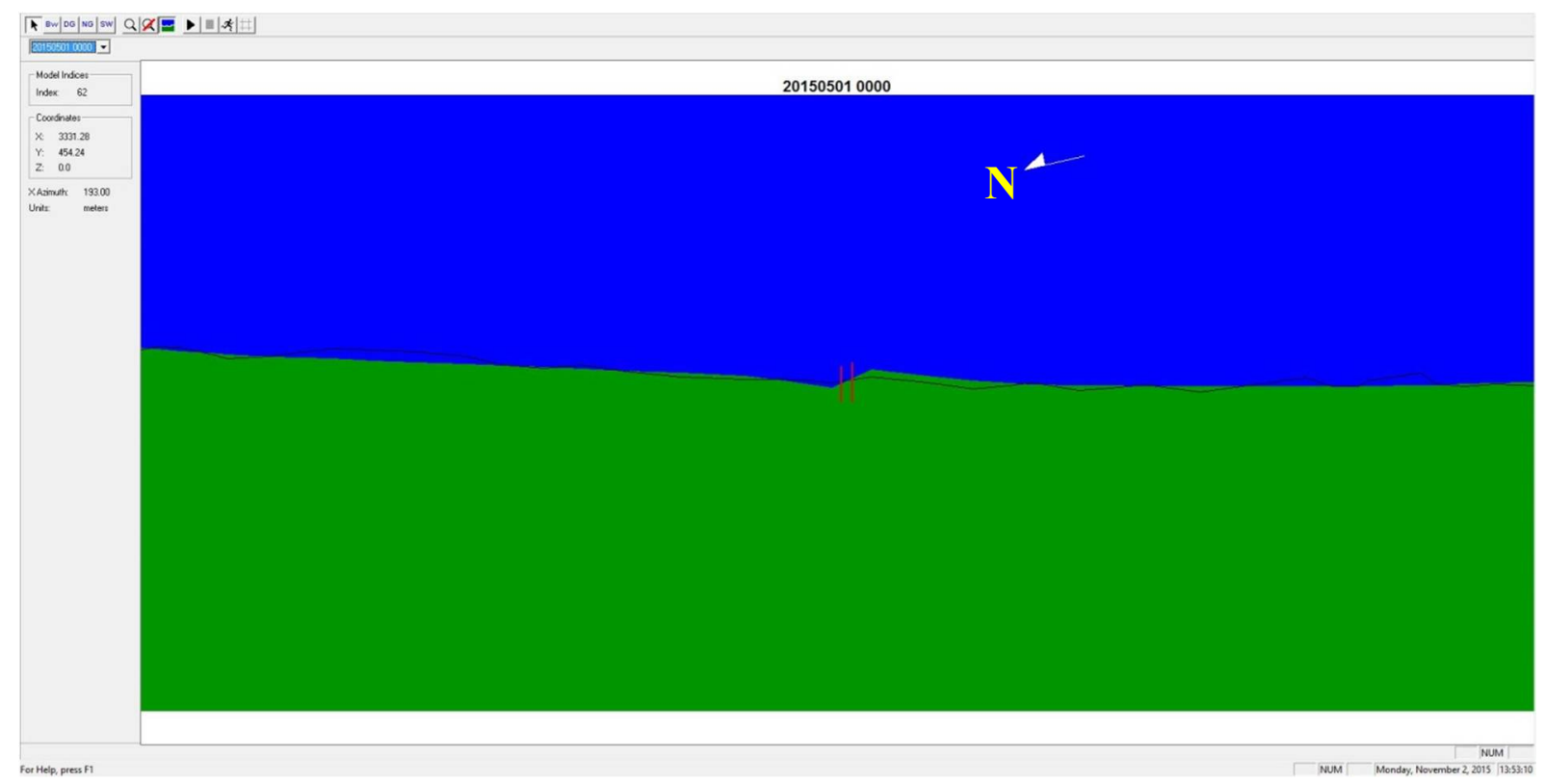

Fig. 14. Forecasted shoreline under the influence of southerly waves ( $2^{\text {nd }}$ Year)

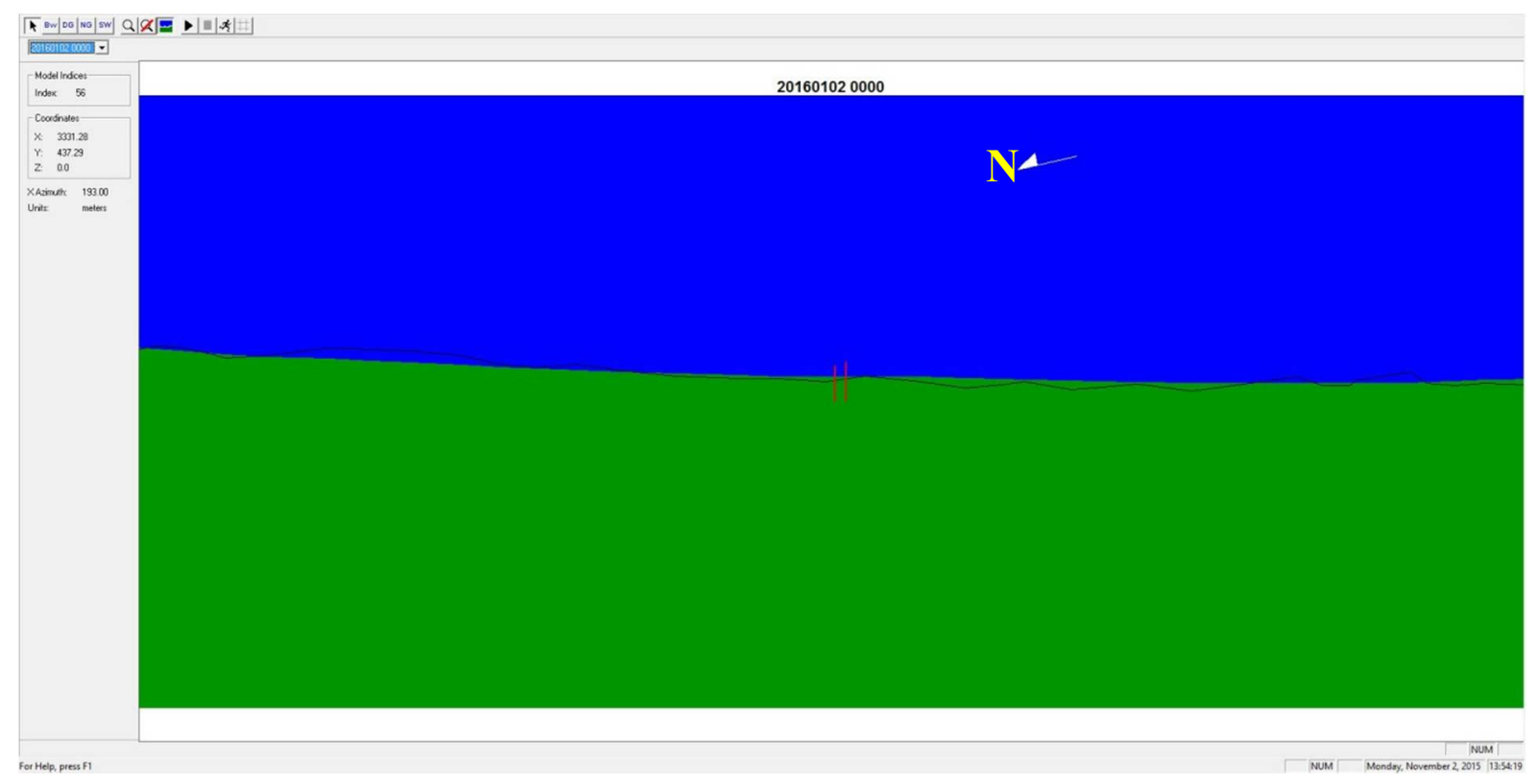

Fig. 15. $2^{\text {nd }}$ Year shoreline change forecast 


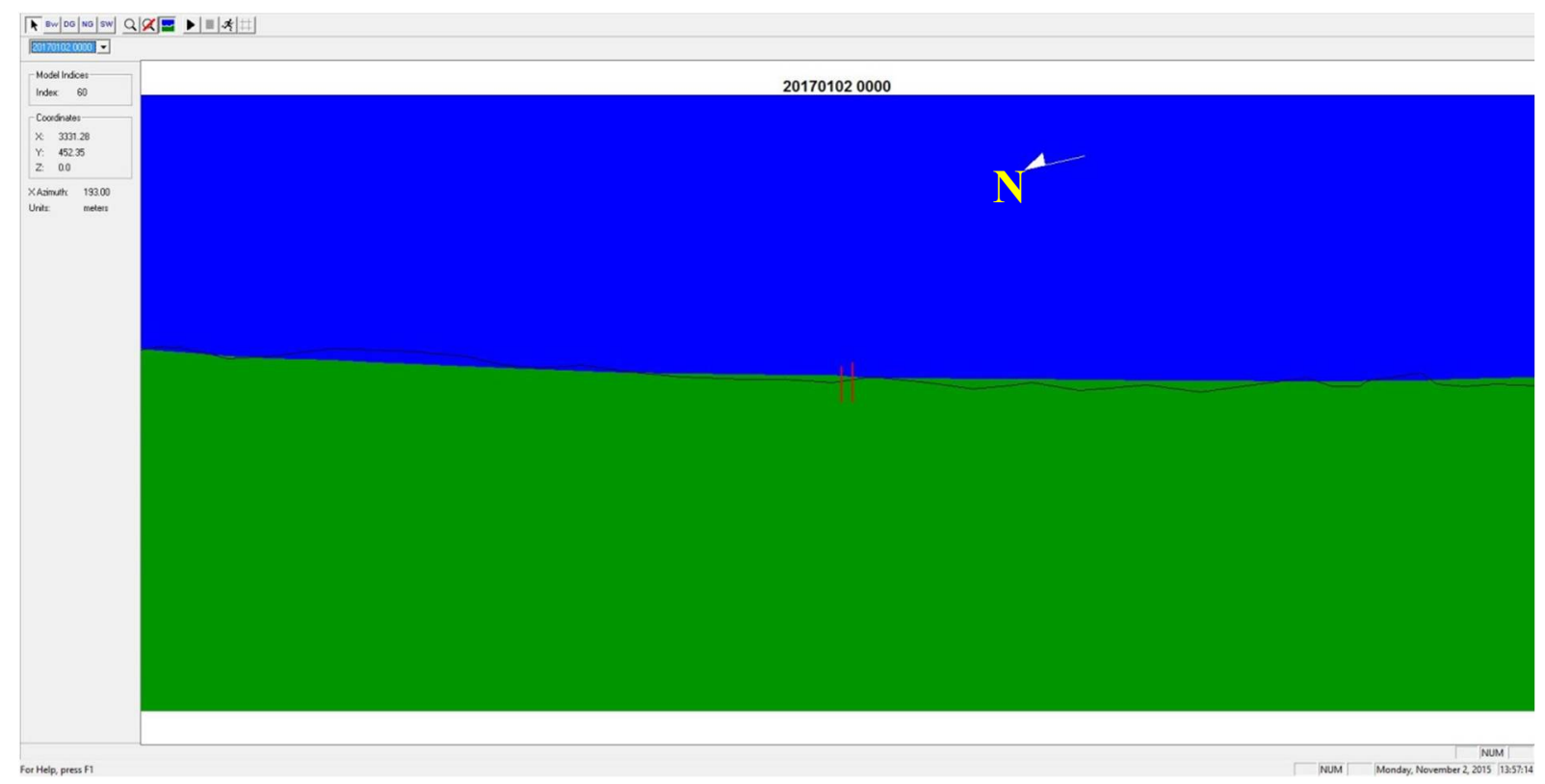

Fig. 16. $3^{\text {rd }}$ Year shoreline change forecast

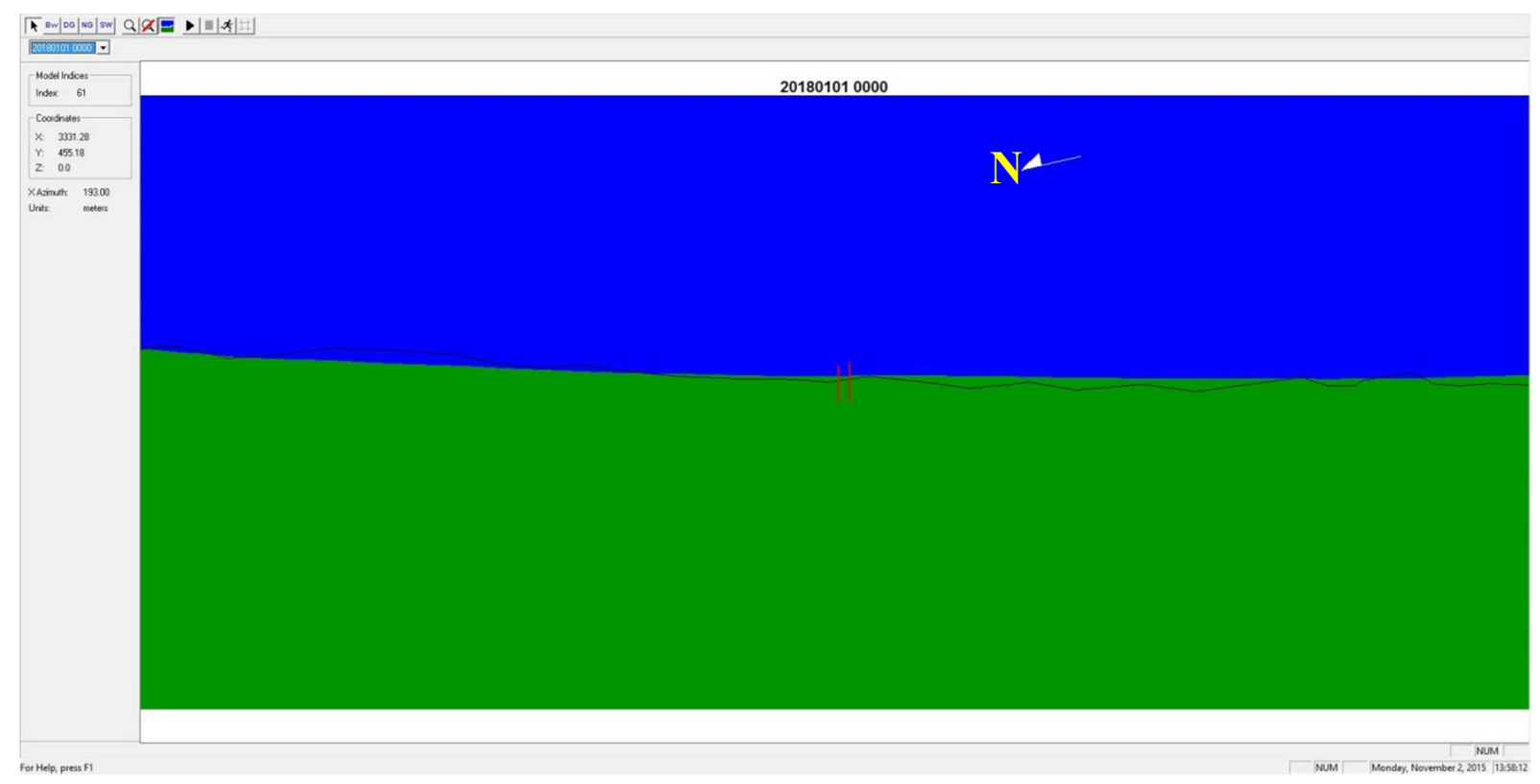

Figure 17: $4^{\text {th }}$ Year shoreline change forecast 


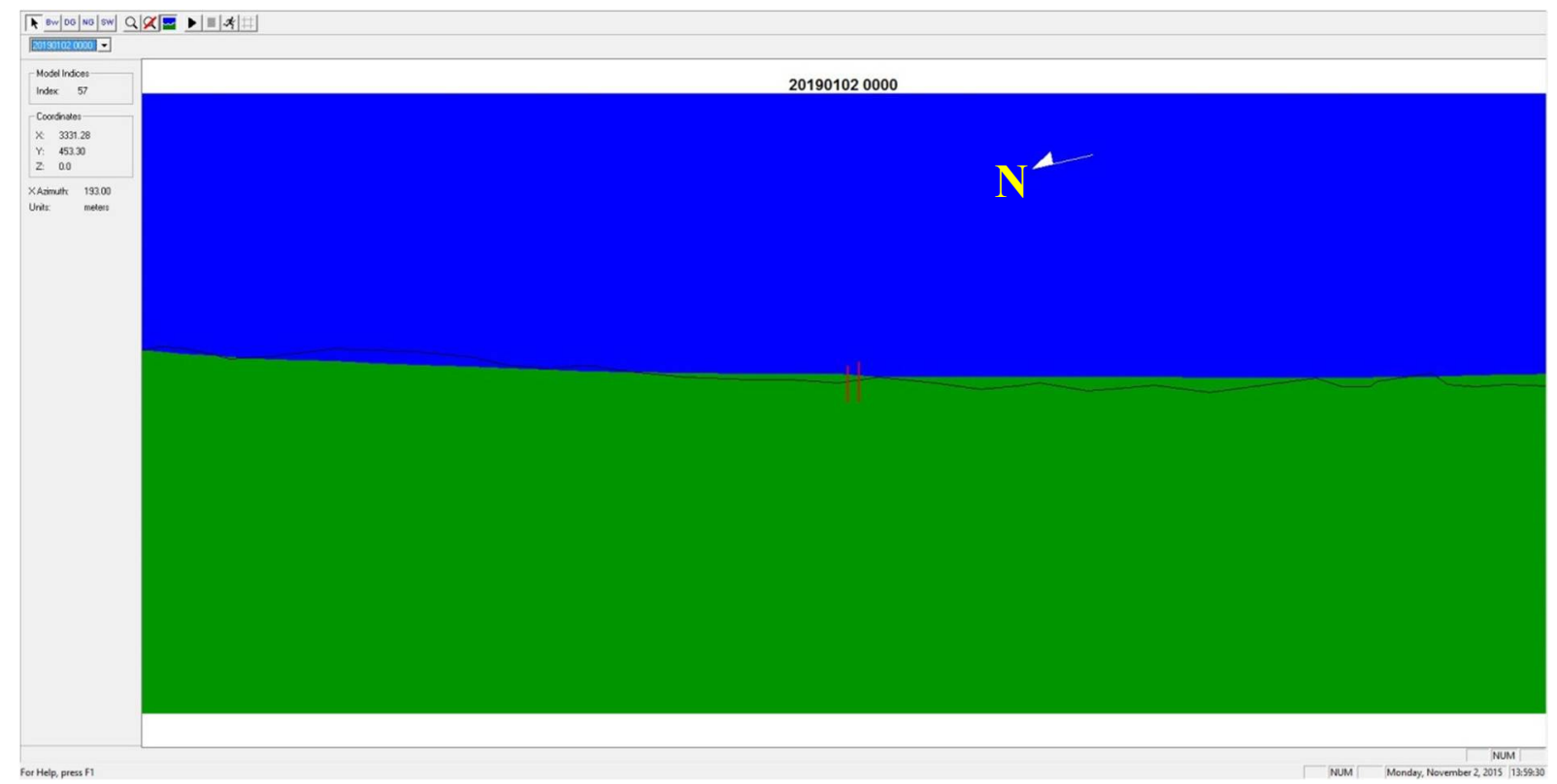

Fig. 18. $5^{\text {th }}$ Year shoreline change forecast

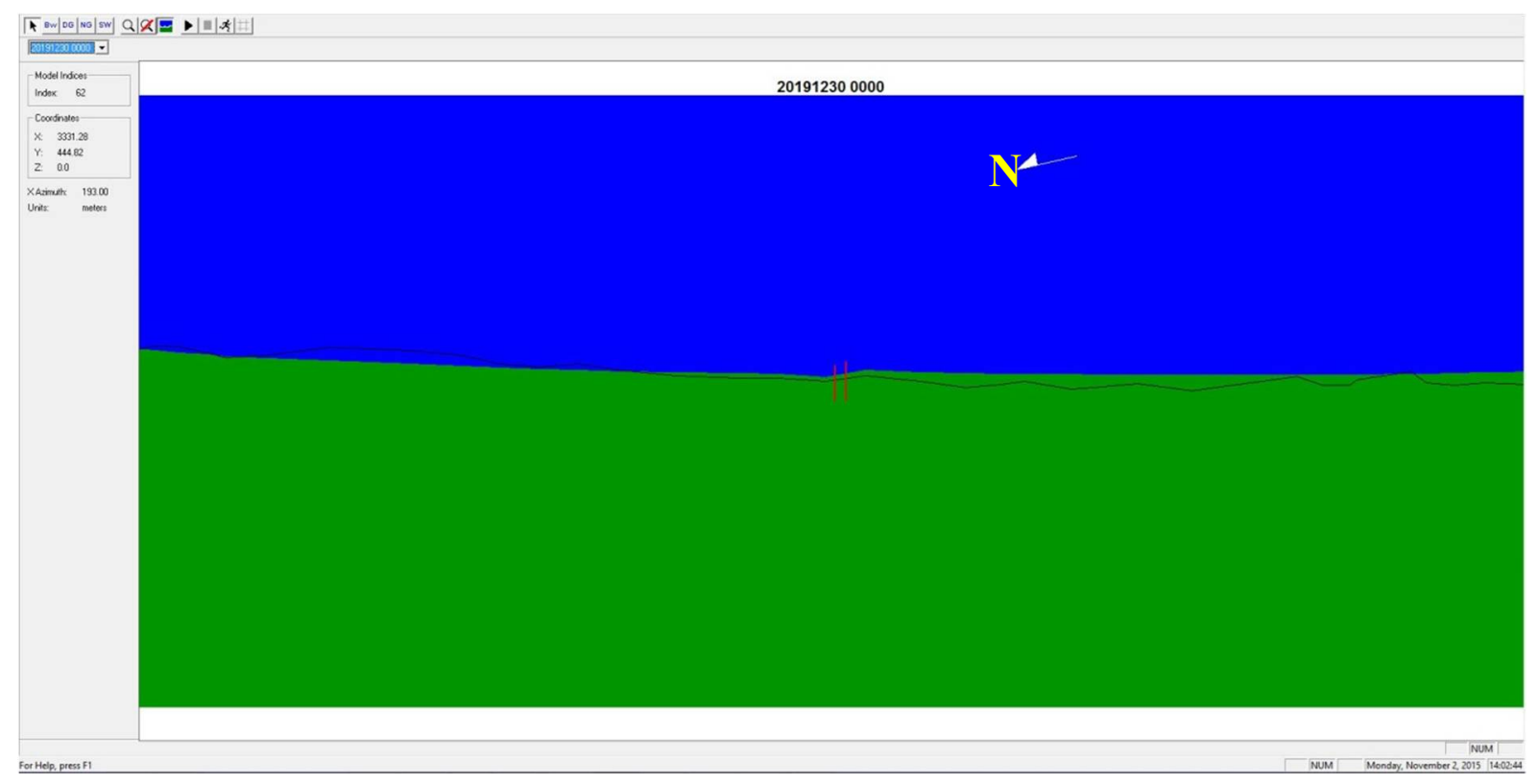

Fig. 19. $6^{\text {th }}$ Year shoreline change forecast 


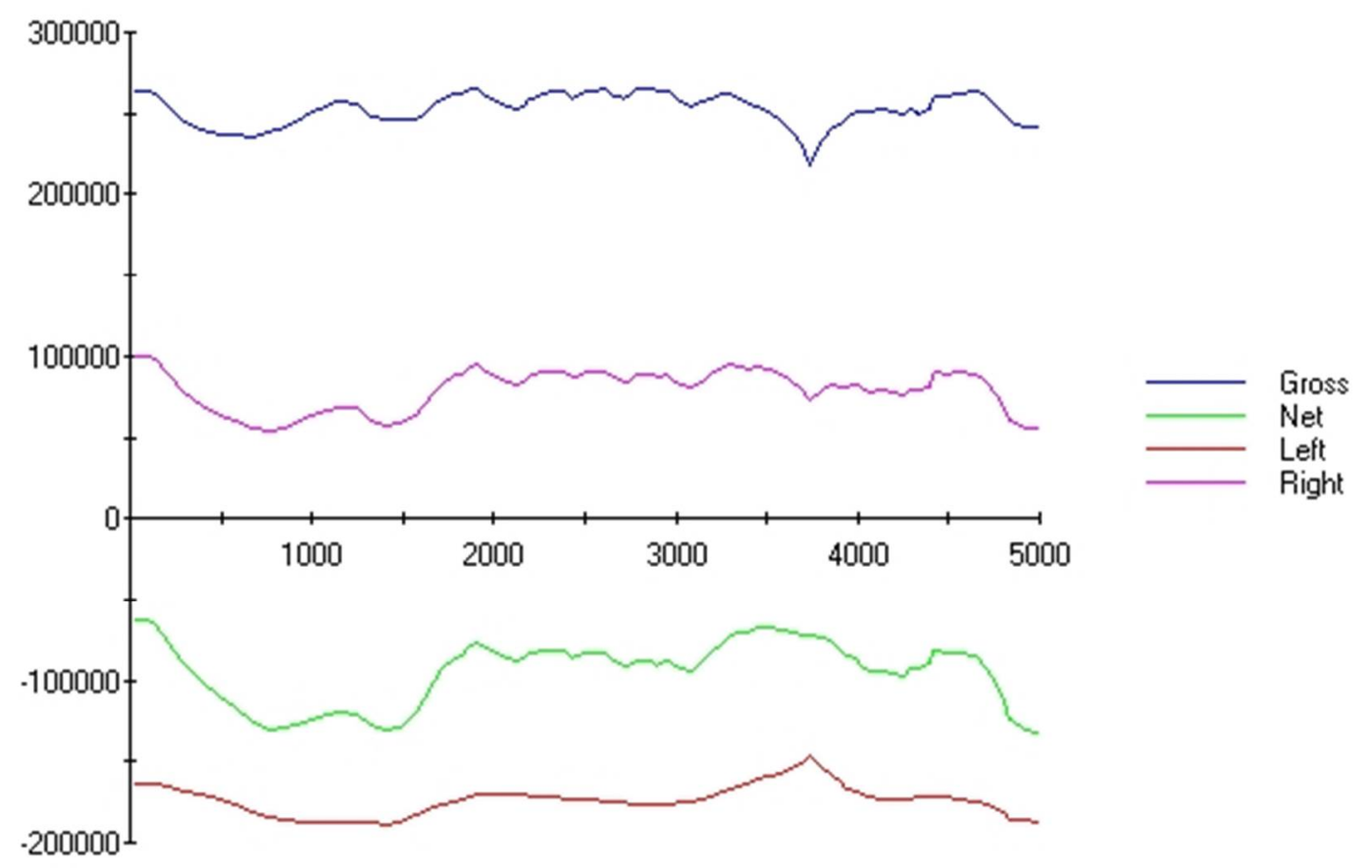

Fig. 20. Sediment Transport Rates

\section{Conclusions}

In this study, a part of Çamyuva Beach located on the south of Kemer district of Antalya Province has been modelled to forecast of coastal line change after construction of a groin structure for prevention of closure of stream mouth. Model has been processed for 6 years. Model results show that the net sediment transport direction is approximately south to north and there will be no significant shoreline change at the loaction.

\section{References}

[1] Web01: http://www.antalyakulturturizm.gov.tr/TR,127688/yabanci-ziyaretci-sayilari-ve-milliyetdagilimi-2012-20-.html

[2] Sultan Baysan, Perceptions of the environmental impacts of tourism: A comparative study of the attitudes of German, Russian and Turkish tourists in Kemer, Antalya, Tourism Geographies, 3:2, 218-235, DOI: 10.1080/14616680010030284, 2001.

[3] Hilal Erkuş-Öztürk, Planning of Tourism Development: The Case of Antalya, Anatolia, 21:1, 107-122, DOI: 10.1080/13032917.2010.9687093, 2010.

[4] Işin Onur, Derya Maktav, Mustafa Sari \& N. Kemal Sönmez, Change detection of land cover and land use using remote sensing and GIS: a case study in Kemer, Turkey, International Journal of Remote Sensing, 30:7, 1749-1757, DOI: 10.1080/01431160802639665, 2009. 
[5] Özhan E., Abdalla S., Türkiye Kıyıları için Rüzgar ve Derin Deniz Dalga Atlası, İnş.Müh.Böl. Deniz Müh. Araş. Mrk., ODTÜ, 1999.

[6] Kraus, N.C., and Harikai, S., Numerical Model of the Shoreline Change at Oarai Beach, Coastal Engineering, 7(1): 1-28, 1983.

[7] Hanson, H., and Kraus, N.C., GENESIS: Generalized Model for Simulating Shoreline Change, Report 1: Technical Reference. Technical Report CERC-89-19, U.S. Army Engineer Waterways Experiment Station, Vicksburg, MS, 1989.

[8] Ozasa, H. and Brampton, A.H., Mathematical Modeling of Beaches Backed by Seawalls, Coastal Engineering, 4(1), 47-64,1980.

[9] Komar, P.D. and Inman, D.L., Longshore Sand Transport on Beaches, Journal of Geophysical Research, 75(30), 5914-5927, 1970.

[10] Kraus, N.C., Isobe, M., Igarashi, H., Sasaki, T. and Horikawa, K., Field Experiments on Longshore Sand Transport in the Surf Zone, Proceedings 18th Coastal Engineering Conference, ASCE, 969-988, 1982.

[11] Longuet-Higgins, M.S., Longshore Currents Generated by Obliquely Incident Sea Waves, 1, Journal of Geophysical Research, 75(33), 6778-6789, 1970.

[12] Office of Navigation, Hydrography and Oceanography Sea Chart 3222.

[13] Google Earth, kh.google.com 